\title{
PENGETAHUAN DAN PERSEPSI PESERTA PROLANIS DALAM MENJALANI PENGOBATAN DI PUSKESMAS
}

\author{
Vivien Dwi Purnamasari \\ Fakultas Ilmu Kesehatan, Institut Ilmu Kesehatan Bhakti Wiyata Kediri \\ Email: vinyd3@gmail.com
}

\begin{abstract}
PROLANIS was a system of health services and proactive approach that can be implemented in an integrated manner involving participants, health facilities, and BPJS. Presence of PROLANISTS would encourage participants with chronic illness to achieve optimal quality of life with an indicator of $75 \%$ had good results on a specific examination. The purpose of this reasearch was to analyzing correlation between knowledge and perceptions of PROLANIS participants with PROLANIS adherence in treatment at Puskesmas. This research design used correlational method with Cross Sectional approach. The population of this research was 101 PROLANIS's participants who have met the inclusion criteria. Samples were taken with total sampling with total of 101 participants. Univariate and bivariate analysis (Chi Square) was used in this research. The results showed PROLANIS adherence level was only $48.5 \%$. In bivariate analysis, knowledge $(p=0,002)$, and perception $(p=0,008)$ correlated to PROLANIS adherence at Puskesmas Kota Kediri. The conclusion is knowledge and perception level correlated to PROLANIS's participants compliance in treatment at Puskesmas. Suggestion in this research is Puskesmas officer can give information related to illness clearly and accurately to PROLANIS's participants and their family.
\end{abstract}

Key words : Adherence PROLANIS, Knowledge, Perception

\begin{abstract}
Abstrak: PROLANIS adalah suatu sistem pelayanan kesehatan dan pendekatan proaktif yang dilaksanakan secara terintegrasi yang melibatkan peserta, fasilitas kesehatan dan BPJS. Adanya kepatuhan PROLANIS akan mendorong peserta penyandang penyakit kronis mencapai kualitas hidup optimal dengan indikator $75 \%$ memiliki hasil yang baik pada pemeriksaan spesifik. Penelitian ini bertujuan untuk mengetahui hubungan tingkat pengetahuan dan persepsi peserta PROLANIS dengan kepatuhan PROLANIS dalam menjalani pengobatan di Puskesmas. Desain penelitian ini menggunakan metode korelasional dengan pendekatan Cross Sectional. Populasi penelitian ini adalah 101 peserta PROLANIS yang telah memenuhi kriteria inklusi. Sampel diambil dengan total sampling dengan jumlah 101 peserta. Pada penelitian ini menggunakan analisa univariat, dan analisa bivariat (Chi Square). Hasil penelitian menunjukkan tingkat kepatuhan PROLANIS hanya sebesar 48,5\%. Pada analisis bivariat diperoleh tingkat pengetahuan $(\mathrm{p}=0,002)$, persepsi $(\mathrm{p}=0,008)$ memiliki hubungan dengan kepatuhan PROLANIS di Puskesmas Kota Kediri. Kesimpulan dari penelitian ini adalah terdapat hubungan tingkat pengetahuan dan persepsi dengan kepatuhan peserta PROLANIS dalam menjalani pengobatan di Puskesmas. Saran pada penelitian ini adalah petugas Puskesmas dapat memberikan informasi terkait penyakit yang diderita dengan jelas dan akurat kepada peserta dan keluarga peserta PROLANIS.
\end{abstract}

Kata Kunci : Kepatuhan PROLANIS, pengetahuan, persepsi 
Program pengelolaan penyakit kronis (PROLANIS) adalah suatu sistem pelayanan kesehatan dan pendekatan proaktif yang dilaksanakan secara terintegrasi yang melibatkan peserta, fasilitas kesehatan, dan BPJS. Penyakit kronis tidak mudah dihadapi bukan hanya karena sifat penyakitnya atau perawatannya, melainkan karena penyakit itu harus diderita untuk waktu yang lama. Penyakit Kronis yang dialami oleh masyarakat dewasa ini akan memberikan dampak dan beban bagi keluarga, bila penanganan dilakukan secara tidak intensif dan berkelanjutan. Manfaat penanganan yang intensif bagi penderita adalah dapat mengenal tanda bahaya dan tindakan segera bila mengalami kegawatdaruratan. Dengan berlakunya Jaminan Kesehatan Nasional sejak Januari 2014, sesuai amanah UndangUndang No. 40 Tahun 2004 tentang Sistem Jaminan Sosial Nasional dan Undang-Undang Nomor 24 Tahun 2011 tentang BPJS, maka Fasilitas

Kesehatan Tingkat Pertama (Puskesmas) sebagai garda terdepan dalam memberikan pelayanan kepada

masyarakat dapat melaksanakan PROLANIS, melalui kerjasama dengan BPJS untuk melakukan pembinaan bagi penderita penyakit kronis.(BPJS, 2010).

Indonesia merupakan negara keempat yang memiliki jumlah Hipertensi juga merupakan penyebab kematian ke- 3 di Indonesia pada semua umur dengan proporsi kematian 6,8\%. Prevalensi Hipertensi menurut hasil Riskesdas Indonesia tahun 2013 di Indonesia yang didapat melalui pengukuran pada umur $\geq 18$ tahun sebesar $25,8 \%$, tetapi yang terdiagnosis oleh tenaga kesehatan atau riwayat minum obat hanya sbesar 9,5\%.(Litbangkes Kemenkes RI, 2013).

PT. ASKES, paling banyak menanggung hingga Rp 10-15 juta rupiah biaya pengobatan DM dengan komplikasi setiap bulannya kepada para peserta. Nilai total biaya perawatan yang dikeluarkan ASKES untuk para pesertanya yang mengalami DM masuk dalam kategori empat besar. Bersama dengan DM, ada penyakit jantung, gagal ginjal terminal, kanker, dan hipertensi. Setelah melihat keadaan tersebut, akhirnya ASKES mengubah haluan strategi penanganan kesehatan. Awalnya penanganan kesehatan lebih banyak berfokus pada kuratif dan rehabilitatif. Namun sekarang promotif dan preventifl yang menjadi fokus dari

pemeliharaan kesehatan. Untuk merealisasikan keseimbangan antara pelayanan dan pembiayaan itu, ASKES menggandeng PERKENI sebagai mitra kerja dalam pelaksanaan PROLANIS. Pemilihan PERKENI didasarkan pada alasan bahwa ASKES lebih menitikberatkan PROLANIS dalam penanganan penyakit DM, sebuah mata rantai dari keahlian klinis para dokter spesialais endrokrinologi (Levesque et al, 2013)

penderita Diabetes Mellitus (DM) terbanyak di dunia. Di Indonesia diperkirakan jumlah diabetisi mencapai 14 juta orang pada tahun 2006, dimana hanya $50 \%$ yang menyadari mengidap Diabetes Mellitus (DM) dan diantaranya sekitar 30\% yang datang berobat secara teratur (Depkes RI, 2013) Menurut laporan Riskesdas tahun 2013 prevalensi DM di Indonesia sebesar 1,5\%. Menurut hasil penelitian yang dilakukan oleh DiabCare di Indonesia, diketahui bahwa 47,2\% memiliki kendali yang buruk pada glukosa darah plasma puasa $>130$ $\mathrm{mg} / \mathrm{dl}$ pada penderita DM tipe 2 (WHO, 2012). Penderita Hipertensi juga belum terdiagnosis dan terjangkau pelayanan kesehatan di masyarakat. 


\section{METODE}

Jenis penelitiannya adalah Explanatory Research, dengan pendekatan Cross sectional. (Notoatmodjo, 2002). Sampel diambil dari populasi adalah semua populasi yang dijadikan sampel atau total populasi yaitu 101 dari 9 Puskesmas yang ada di Kota Kediri untuk penelitian kuantitatif. Kriteria populasi adalah usia antara 46-65 tahun; tidak mengalami komplikasi DM tipe II dan Hipertensi, bersedia menjadi responden dan berada di tempat pada saat penelitian. Instrumen pengumpulan data penelitian ini berbentuk kuesioner terstruktur dengan wawancara. Semua responden diwawancarai tentang kepatuhan PROLANIS. Variabel independen yang diteliti usia, jenis kelamin, status pekerjaan, tingkat pengetahuan, dan persepsi peserta PROLANIS tentang kepatuhan menjalani pengobatan.

\section{HASIL PENELITIAN}

1. Distribusi Responden Berdasarkan Karakteristik Responden di Puskesmas Kota Kediri

\begin{tabular}{lcc}
\hline Karakteristik Responden & Frekuensi & Persentase (\%) \\
\hline Kelompok Umur & & \\
$\quad$ Lansia (46-64 tahun) & 40 & 39,6 \\
$\quad$ Manula ( $\geq 65$ tahun) & 61 & 60,4 \\
Jenis Kelamin & & \\
$\quad$ Laki-laki & 36 & 35,6 \\
Perempuan & 65 & 64,4 \\
Status Pekerjaan & & \\
$\quad$ Masih Bekerja & 16 & 15,8 \\
Tidak Bekerja & 85 & 84,2 \\
\hline
\end{tabular}

2. Distribusi Responden Berdasarkan Tingkat Pengetahuan, Persepsi Responden dan Kepatuhan PROLANIS

\begin{tabular}{lcc}
\hline \multicolumn{1}{c}{ Variabel } & Frekuensi & Persentase (\%) \\
\hline Pengetahuan & & \\
$\quad$ Buruk & 58 & 57,43 \\
Baik & 43 & 42,57 \\
Persepsi & & \\
Kurang & 54 & 53,5 \\
Baik & 47 & 46,5 \\
Kepatuhan & & \\
Tidak Patuh & 52 & 51,5 \\
Patuh & 49 & 48,5 \\
\hline
\end{tabular}

Sebagian besar usia responden dalam penelitian ini $60,4 \%$ yaitu manula ( $\geq 65$ tahun) sedangkan $39,6 \%$ adalah usia lansia (46-64 tahun). Responden dalam penelitian ini sebagian besar perempuan $(64,4 \%)$.Padamasa pengobatan responden dalam penelitian ini sebagian besar tidak bekerja tidak bekerja adalah $84,2 \%$.
Sebagian besar responden mempunyai pengetahuan yang buruk tentang PROLANIS yaitu sebanyak 58 responden $\quad(57,43 \%)$. Responden mempunyai persepsi yang buruk tentang PROLANIS yaitu sebanyak 54 responden $(53,5 \%)$. Sebagian besar responden tidak patuh terhadap 
PROLANIS di Puskesmas yaitu sebanyak 52 responden (48,5\%)

3. Hubungan Tingkat Pengetahuan dan Persepsi dengan Kepatuhan PROLANIS

\begin{tabular}{lccccccc}
\hline \multirow{2}{*}{ Variabel } & \multicolumn{2}{c}{ Tidak Patuh } & \multicolumn{2}{c}{ Patuh } & \multicolumn{2}{c}{ Jumlah } & \multirow{2}{*}{$\boldsymbol{p}$-value } \\
\cline { 2 - 6 } & $\mathbf{n}$ & $\mathbf{\%}$ & $\mathbf{n}$ & $\mathbf{\%}$ & $\mathbf{N}$ & $\mathbf{\%}$ & \\
\hline Pengetahuan & 38 & 65,51 & 20 & 34,49 & 58 & & \\
$\quad$ Buruk & 14 & 32,56 & 29 & 67,44 & 43 & 100 & 0,002 \\
$\quad$ Baik & 35 & 64,81 & 19 & 35,19 & 54 & & \\
Persepsi & 17 & 36,17 & 30 & 63,83 & 47 & 100 & 0,008 \\
$\quad$ Kurang & Baik & & & & & & \\
\hline
\end{tabular}

Berdasarkan tabel 3 menunjukkan bahwa responden yang tidak patuh dalam PROLANIS lebih banyak dijumpai pada kelompok responden yang memiliki pengetahuan buruk $(65,51 \%)$ dibandingkan dengan kelompok responden yang memiliki pengetahuan baik $(32,56 \%)$. Sedangkan responden yang patuh dalam PROLANIS lebih banyak dijumpai pada kelompok responden yang memiliki

pengetahuan baik $(67,44 \%)$ dibandingkan dengan kelompok responden yang memiliki pengetahuan buruk $(34,49 \%)$. Hasil uji chi square dengan taraf signifikansi $5 \%$ diperoleh nilai $p$-value 0,002 yang berarti bahwa nilai $\mathrm{p}<0,05$, jadi Ho ditolak, sehingga kesimpulannya ada hubungan antara tingkat pengetahuan dengan kepatuhan PROLANIS di Puskesmas Kota Kediri Responden yang tidak patuh dalam PROLANIS lebih banyak dijumpai pada kelompok responden yang memiliki persepsi kurang $(64,81 \%)$ dibandingkan dengan kelompok responden yang memiliki persepsi baik $(36,17 \%)$. Sedangkan responden yang patuh dalam PROLANIS lebih banyak dijumpai pada kelompok responden yang memiliki persepsi baik $(63,83 \%)$ dibandingkan dengan kelompok responden yang memiliki persepsi kurang (35,19\%). Hasil uji chi square dengan taraf signifikansi $5 \%$ diperoleh nilai $p$ value 0,008 yang berarti bahwa nilai $\mathrm{p}<0,05$, jadi Ho ditolak, sehingga kesimpulannya ada hubungan persepsi dengan kepatuhan PROLANIS di Puskesmas Kota Kediri.

\section{PEMBAHASAN}

Pelaksanaan

PROLANIS

dilaksanakan berdasarkan Buku Panduan Pelaksanaa PROLANIS sesuai dengan Peraturan No.12 Tahun 2013

tentang Jaminan Kesehatan. Berdasarkan dasar tersebut diketahui bahwa pelaksana PROLANIS di Puskesmas baru terlaksana yaitu penyuluhan kesehatan, pemeriksaan kesehatan, senam PROLANIS, dan pemberian obat. Tata laksana kegiatan pada Puskesmas berbeda karena tidak ada SOP untuk PROLANIS.

Kepatuhan peserta PROLANIS di Puskesmas ditunjukkan dengan peserta PROLANIS rutin mengikuti semua kegiatan PROLANIS di Puskesmas yang dilakukan setiap bulan di Puskesmas. Kegiatan-kegiatan tersebut antara lain adalah konsultasi medis peserta PROLANIS, mengikuti edukasi kelompok peserta PROLANIS, senam yang dilakukan pagi hari. Tujuan PROLANIS adalah mendorong peserta penyandang penyakit kronis mencapai kualitas hidup dan dapat mencegah timbulnay komplikasi penyakit. Menurut Skinner (dalam Purwanta, 2006) perilaku kesehatan (health behavior) termasuk kepatuhan dalam menjalankan pengobatan adalah respons seseorang terhadap stimulus atau objek uang berkaitan dengan sehat-sakit,penyakit, dan faktorfaktor yang mempengaruhi sehat-sakit (kesehatan). Smet (dalam 
Cramer,(1991) mendefinisikan kepatuhan(ketaatan) sebagai tingkat penderita melaksanakan cara pengobatan dan perilaku yang disarankan oleh dokternya atau yang lain. Penelitian ini untuk mengetahui kepatuhan peserta

PROLANIS dalam menjalani pengobatan di Puskesmas. Hasil penelitian menunjukkan bahwa $(51,5 \%)$ responden dikategorikan tidak patuh terhadap PROLANIS dan $(48,5 \%)$ responden dikategorikan patuh terhadap PROLANIS.

\section{Pengetahuan Terhadap Kepatuhan PROLANIS Di Puskesmas}

Pengetahuan dapat diartikan
sebagai kumpulan informasi yang dipahami, diperoleh dari proses belajar selama hidup dan dapat dipergunakan sewaktu-waktu sebagai alat penyesuaian diri, baik terhadap diri sendiri maupun lingkungan. Pengetahuan tentang suatu objek dapat diperoleh dari pengalaman guru, orang tua, teman, buku dan media massa. Penderita yang mempunyai pengetahuan tinggi cenderung lebih patuh berobat daripada penderita yang berpengetahuan rendah (Notoatmodjo, 2003). Penderita yang mempunyai tingkat pengetahuan baik akan dapat menjadi guru yang baik bagi dirinya, dengan pengetahuan yang dimiliki akan mempengaruhi kepatuhan peserta tersebut untuk lebih patuh dalam PROLANIS dan dapat melakukan semua kegiatan yang ada dalam PROLANIS karena dapat memberi manfaaat bagi kesehatan dalam dirinya.

Kepatuhan adalah kesesuaian antara perilaku pasien dengan ketentuan yang diberikan obat sesuai jangka waktu yang ditentukan dan rutin kontrol ke Instansi. Lamanya proses pengobatan kadang membuat penderita jenuh sehingga beresiko mengalami putus obat yang bisa menjadikan pengobatan tidak tuntas hingga akhirnya penderita sulit disembuhkan.

Berdasarkan hasil analisis bivariat menunjukkan bahwa ada hubungan antara pengetahuan responden dengan kepatuhan PROLANIS yaitu $p$ value sebesar $(0,002)$. Hal ini sesuai dengan teori Lawrence Green yang menyatakan bahwa perilaku patuh itu dipengaruhi oleh faktor-faktor predisposisi, salah satunya pengetahuan responden. Hasil penelitian ini diperkuat oleh penelitian yang telah dilakukan (Annisa \& Ansar, 2013) yang menunjukkan bahwa ada hubungan antara pengetahuan dengan kepatuhan berobat . Hal ini dikarenakan dengan mensosialisasikan pentingnya menjalani pengobatan yang teratur bagi penderita hipertensi, penyuluhan kesehtan mengenai penyakit hipertensi dan DM , pemberian brosur tentang penyakit hipertensi dan DM. Hal ini secara tidak langsung mampu meningkatkan pengetahuan bagi peserta PROLANIS sehingga dapat memotivasi peserta untuk patuh dalam melakukan semua kegiatan dalam PROLANIS.

\section{Persepsi terhadap Kepatuhan PROLANIS di Puskesmas}

Persepsi adalah kemampuan otak dalam menerjemahkan stimulus atau proses untuk menerjemahkan stimulus yang masuk ke dalam alat indera manusia. Persepsi manusia terdapat perbedaan sudut pandang dalam penginderaan (Notoatmodjo, 2003) Persepsi mempunyai sifat subjektif karena bergantung pada kemampuan dan keadaan masing-masing individu sehingga akan ditafsirkan berbeda oleh individu yang satu dengan yang lain. Dengan demikian persepsi merupakan proses perlakuan individu yaitu memberi tanggapan, arti,gambaran atau penginterpretasian terhadap apa yang dilihat, didengar, atau dirasakan oleh indranya dalam bentuk sikap, pendapat dan tingkah laku atau disebut prilaku individu.

Berdasarkan analisis bivariat menunjukkan adanya hubungan antara persepsi responden dengan kepatuhan dalam PROLANIS yaitu $p$-value sebesar $(0,008)$. Menurut di lapangan dari 101 responden diperoleh responden yang patuh karena mempunyai persepsi baik $(63,83 \%)$ sedangkan responden yang tidak patuh karena persepsi yang kurang 
$(64,81 \%)$. Sehingga bisa disimpulkan responden patuh dalam PROLANIS jika mempunyai persepsi yang baik tentang PROLANIS bagi kesembuhan penyakitnya. Persepsi sangatlah dipengaruhi oleh konsep yang dibuat pasien terhadap penyakitnya.

Konsep tersebut berupa pemahaman. Proses memahami diartikan dapat menginterpretasikan obyek secara benar (Notoatmojo, 2003).

Persepsi seseorang dalam menangkap informasi dan peristiwaperistiwa menurut Kotler (Gunadarma, 2011) dipengaruhi oleh tiga faktor, yaitu: orang yang membentuk persepsi itu sendiri, khususnya kondisi intern (kebutuhan, kelelahan, sikap, minat, motivasi, harapan, pengalaman masa laludan kepribadian, yang kedua adalah stimulus yang berupa obyek maupun peristiwa tertentu (benda, orang, proses dan lain-lain), dan yang terakhir adalah stimulus dimana pembentukan persepsi itu terjadi baik tempat, waktu, suasana (sedih, gembira dan lain-lain).

\section{KESIMPULAN}

Berdasarkan hasil penelitian maka dapat disimpulkan

1. Sebagian besar responden dalam kategori tidak patuh PROLANIS di Puskesmas Kota Kediri

2. Ada hubungan Tingkat pengetahuan dengan kepatuhan peserta PROLANIS dalam menjalani pengobatan di Puskesmas Kota Kediri

3. Ada hubungan persepsi mempunyai hubungandengankepatuhan

$\begin{array}{llr}\text { peserta } & \text { PROLANIS } & \text { dalam } \\ \text { menjalani } & \text { pengobatan } & \text { di } \\ \text { Puskesmas } & \text { Kota Kediri } & \end{array}$

\section{SARAN}

1. Petugas Puskesmas dapat memberikan informasi terkait dengan penyakit yang diderita oleh peserta PROLANIS dengan jelas dan akurat dengan cara memberikan waktu konsultasi yang lebih lama kepada peserta PROLANIS.
2. Petugas Puskesmas melakukan pemantauan kesehatan baik dalam bentuk home visit atau dalam bentuk sms kepada peserta PROLANIS yang tidak bisa hadir pada waktu PROLANIS tersebut.

\section{DAFTAR PUSTAKA}

Annisa, A.F.N. \& Ansar, J.(2013). FAKTOR YANG BERHUBUNGAN DENGAN KEPATUHAN BEROBAT HIPERTENSI PADA LANSIA DI PUSKESMAS PATTINGALLOANG KOTA MAKASSAR. , 1, pp.1-11.

BPJS. (2010). Panduan praktis PROLANIS (Program pengelolaan penyakit kronis). BPJS Kesehatan, pp.3-6.

Cramer. (1991). Compliance and MedicalPractice Clinical Trial. Dari http://www.pudmed.guv.

Depkes RI. (2013). Profil Kesehatan Indonesia Tahun 2013, Jakarta: Departemen Kesehatan.

Dinas Kesehatan Kota Kediri. (2015).Profil Kesehatan Kota Kediri Tahun 2015.

Gunadarma.(2011). Psikologi Umum. Dari

http://elearning.gunadarma.ac.id/ doc modul/psikologi_umum_1/Bab_3 .pdf.

Levesque, J.-F., Harris, M.F. \& Russell, G.(2013). Patient-centred access to health care: conceptualising access at the interface of health systems and populations. International journal for equity in health, 12(1), p.18. Available at: http://www.equityhealthj.com/cont ent $/ 12 / 1 / 18$.

Litbangkes Kemenkes RI. (2013). Riset Kesehatan Dasar. , pp.1-306.

Notoatmodjo, soekidjo. (2002). Metodologi Penelitian Kesehatan P. R. Cipta, ed., Jakarta.

Notoatmodjo, soekidjo. (2003). Pendidikan dan Perilaku Kesehatan, Jakarta: PT. Rineka Cipta. 
Remedan, A. et al., (2015). An Assessment of Adherence of PatientstoAnti-Hypertensive Medication and Factors for NonAdherence in Oromia Region Adama Referral Hospital, Ethiopia. Gjmr, 15(1), pp.29-36.

Runtukahu, R.F., Rompas, S. \& Pondaag, L.. (2015). ANALISIS FAKTOR-FAKTOR YANG BERHUBUNGAN DENGAN KEPATUHAN MELAKSANAKAN DIET PADA PENDERITA HIPERTENSI DI WILAYAH KERJA PUSKESMAS WOLAANG
KECAMATAN LANGOWAN TIMUR. , 3.

Violita, F. (2015). HIPERTENSI DI WILAYAH KERJA PUSKESMAS SEGERI. , p.2015.

WHO.(2012).AboutDiabetes [Internet]. Available from: http:www.who.int/diabetes/action_ online/basics/en/index $3 . h t m l$ 